\title{
SISTEM INFORMASI BEASISWA YAYASAN AMAL ABADI BEASISWA ORANG TUA BIMBING TERPADU HASRI AINUN HABIBIE
}

\author{
Priatmoko, Indriyati \\ Ilmu Komputer / Informatika FSM Universitas Diponegoro \\ priatmoko.informatics@gmail.com,indri52@yahoo.com
}

\begin{abstract}
ABSTRAK
Yayasan Amal Abadi Beasiswa Orang Tua Bimbing Terpadu Hasri Ainun Habibie merupakan yayasan sosial yang memberikan dana bantuan berupa beasiswa studi kepada pelajar tingkat SD, SMP, SMA, dan perguruan tinggi. Proses penyaluran dana beasiswa yang berjalan saat ini seperti pemberitaan, pendaftaran, dan seleksi penerima beasiswa masih belum memanfaatkan teknologi informasi sehingga proses berjalan kurang optimal. Dengan adanya teknologi internet saat ini, dapat dibangun sebuah sistem informasi beasiswa berbasis web untuk melakukan pemberitaan, pendaftaran, dan seleksi penerima beasiswa secara online. Sistem informasi ini dikembangkan menggunakan bahasa pemrograman PHP dan sistem manajemen basis data $M y S Q L$. Proses pengembangan sistem informasi menggunakan metode pengembangan perangkat lunak Unified Process, sedangkan proses perangkingan pendaftar beasiswa sebagai pertimbangan pengambilan keputusan menggunakan metode Simple Additive Weighting. Sistem informasi ini dapat digunakan untuk melakukan pendaftaran beasiswa secara online, pengelolaan konten website, dan menghasilkan perangkingan pendaftar beasiswa.
\end{abstract}

Kata kunci : Sistem Informasi, Beasiswa, Unified Process, Simple Additive Weighting

\section{PENDAHULUAN}

Yayasan Amal Abadi Beasiswa Orang Tua Bimbing Terpadu Hasri Ainun Habibie (Yayasan AAB ORBIT HAH) merupakan sebuah organisasi sosial yang memiliki tujuan utama ikut berperan serta menunjang program pemerintah republik Indonesia dalam bidang pendidikan, pengembangan, dan peningkatan sumber daya manusia. Perwujudan dari peran serta yayasan dalam menunjang program pemerintah dilakukan dengan memberikan pendidikan dan pelatihan, merancang, membiayai dan melaksanakan berbagai program untuk meningkatkan kemampuan sumber daya manusia [1].

Salah satu tugas utama yayasan dalam menunjang program pemerintah adalah menyalurkan dana beasiswa kepada siswa atau mahasiswa di seluruh Indonesia. Dalam menyalurkan dana beasiswa, yayasan memiliki beberapa perwakilan yayasan di daerah untuk membantu melakukan pendataan dan seleksi terhadap siswa atau mahasiswa yang membutuhkan dana beasiwa. Proses pendataan dan seleksi dimulai dengan melakukan pemberitaan dana beasiswa di sekolah-sekolah atau perguruan tinggi. Pemberitaan akan memberikan informasi mengenai tatacara melakukan pendaftaran beasiswa dan persyaratan-persyaratan yang harus dipenuhi oleh siswa atau mahasiswa yang berminat untuk melakukan pendaftaran beasiswa.

Dengan melihat kondisi yang ada sekarang ini, sekretariat yayasan sebagai penyelenggara program beasiswa bermaksud untuk memulai membangun sistem informasi yang dapat memenuhi kebutuhan proses-proses penyaluran dana beasiswa.

Unified Process merupakan salah satu software development process yang menerapkan konsep berorientasi objek yang dikembangkan oleh Ivar Jacobson, Grady Booch, dan James Rumbaugh. Unified Process bersifat open, free, dan tidak terikat dengan vendor tertentu. Oleh karena itu, proses pengembangan sistem informasi ini menggunakan Unified Process sehingga diharapkan dihasilkan perangkat lunak yang berkualitas tinggi, reusable, dan mudah untuk dipelihara [5].

Pembangunan sistem pendukung keputusan, penulis memilih salah satu metode dari model Multiple Attribute Decission Making (MADM) yaitu Simple Additive Weighting (SAW). Metode ini dipilih karena mampu menyeleksi alternatif terbaik dari sejumlah 
alternatif berdasarkan pada kriteria-kriteria tertentu [8],

\section{DASAR TEORI}

\subsection{Sistem Informasi}

Sistem adalah kumpulan dari komponen yang saling berhubungan satu dengan yang lainnya membentuk satu kesatuan untuk mencapai tujuan tertentu. Informasi adalah data yang diolah menjadi bentuk yang berguna bagi para pemakainya. Suatu informasi dapat berguna jika memenuhi tiga pilar yaitu tepat kepada orangnya atau relevan, tepat waktu, dan tepat nilai atau akurat [6].

Sistem informasi merupakan sekumpulan elemen yang terintegrasi yang digunakan untuk mengubah data menjadi informasi . Sistem informasi terbentuk dari beberapa komponen yang saling berhubungan. Komponen-komponen tersebut meliputi input, model, basis data, output, teknologi, dan kontrol [6].

\subsection{Multiple Attribute Decission Making (MADM)}

Multiple Atribut Decission Making merupakan suatu pendekatan yang digunakan untuk mengambil keputusan diantara alternatifalternaif yang terbatas atau telah diketahui jumlahnya. Tabel keputusan atau matrik keputusan pada MADM memiliki empat bagian utama, yakni alternatives (A), attributes (B), weight (W), measures of performance of alternatives with respect to the attributes (M) [8]

\subsection{Simple Additive Weighting (SAW) Method}

Simple additive weighting method atau weighted sum method merupakan salah satu metode pengambil keputusan dari Multiple Atribute Decision Making. Pada awalnya metode SAW hanya digunakan untuk memberikan perangkingan pada alternatif dengan atributatribut yang memiliki satuan sama, misalnya hanya rupiah, hanya meter, hanya liter, dan lainlain.

Pada perkembangannya metode SAW dapat digunakan untuk alternatif-alternatif dengan berbagai atribut asalkan semua elemen matrik keputusan atau tabel keputusan telah dinormalisasi. Rumus perangkingan yang digunakan adalah persamaan 2.1.

$$
P_{i}=\sum_{j=1}^{M} w_{j}\left(m_{i j}\right)_{n o r m a l}
$$

Proses normalisasi matriks keputusan dilakukan dengan mendefinisikan atribut beneficial dan atribut non-beneficial. Rumus normalisasi matrik keputusan adalah:

$$
\begin{aligned}
& m_{i j n o r m a l}=\frac{m_{i j}}{\operatorname{MAX}\left(m_{i j}\right)} \text { beneficial attribute } \\
& \left.m_{i j n o r m a l}=\frac{\operatorname{MIN}\left(m_{i j}\right)}{m_{i j}}\right)_{\text {non-beneficial atribute }}(2.3)
\end{aligned}
$$

Keterangan:

$$
\begin{array}{ll}
\mathrm{P}_{\mathrm{i}} & =\text { nilai alternatif } \\
\mathrm{W} & =\text { bobot atribut } \\
\mathrm{m}_{\mathrm{ij}} & =\text { nilai rating atribut } \\
\mathrm{m}_{\mathrm{ijnormal}} & =\text { nilai rating atribut } \\
& \text { ternormalisasi } \\
\mathrm{M} & =\text { jumlah atribut }
\end{array}
$$

Nilai Pi yang tertinggi adalah nilai alternatif yang terbaik.

\subsection{Unified Process}

Unified Software Development Process atau biasa disebut sebagai Unified Process merupakan suatu proses pengembangan perangkat lunak [5], terutama untuk perangkat lunak yang dibuat berorientasi objek.

Unified Process memiliki dua dimensi yaitu dimensi horizontal dan dimensi vertical. Dimensi horizontal mewakili aspek-aspek dinamis dari pengembangan perangkat lunak. Aspek ini dijabarkan dalam tahapan pengembangan atau fase. Setiap fase akan memiliki suatu major milestone yang menandakan akhir dari awal dari fase selanjutnya. Dimensi ini terdiri atas Inception, Elaboration, Construction, dan Transition. Dimensi vertikal mewakili aspek-aspek statis dari proses pengembangan perangkat lunak yang dikelompokkan ke dalam beberapa disiplin yang meliputi requirement, analysis, design, implementation, dan test.

\section{ANALISIS DAN PERANCANGAN}

\subsection{Fase Inception}

\subsubsection{Activity Diagram}

Gambar 3.1 merupakan activity diagram sistem informasi yang menggambarkan proses- 
proses bisnis pengelolaan beasiswa, sedangkan gambar 3.2 merupakan activity diagram yang menggambarkan proses bisnis pengelolaan konten website yayasan.

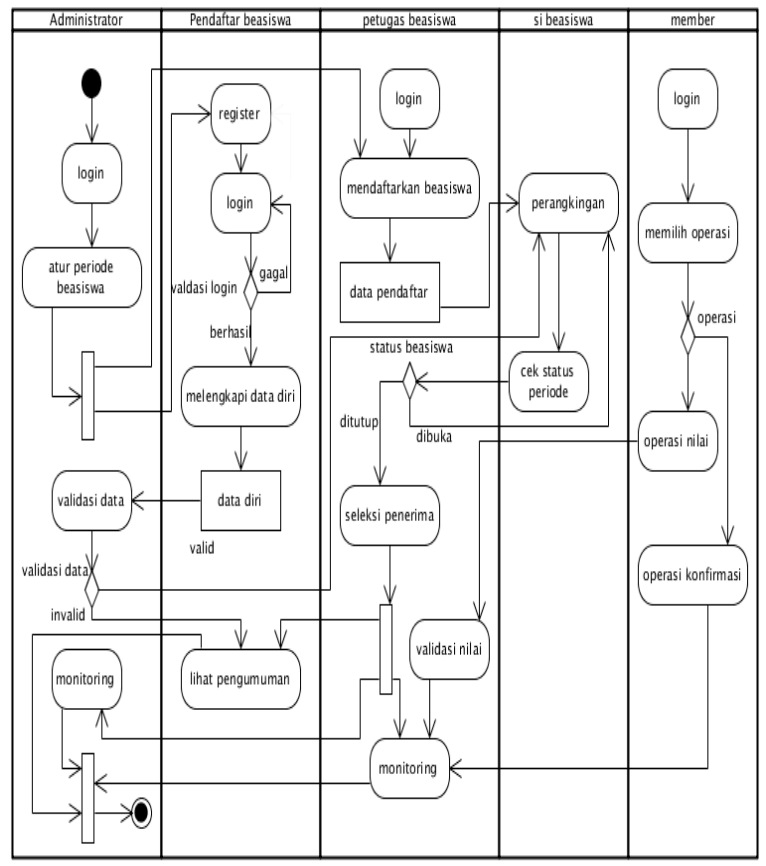

Gambar 3.1 Activity Diagram Sistem Informasi Beasiswa

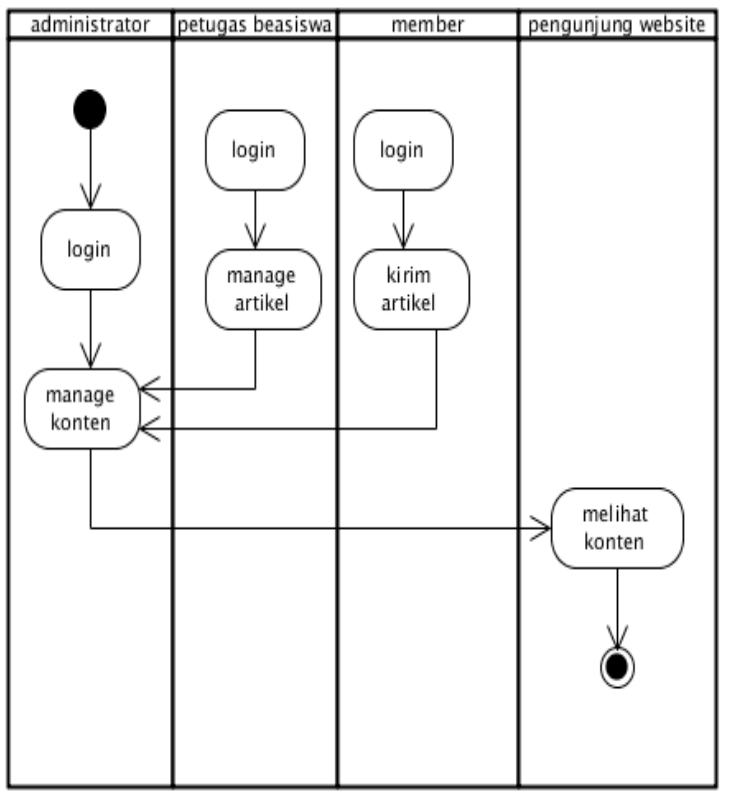

Gambar 3.2 Activity Diagram Manajemen Konten Website

\subsubsection{Use Case Diagram}

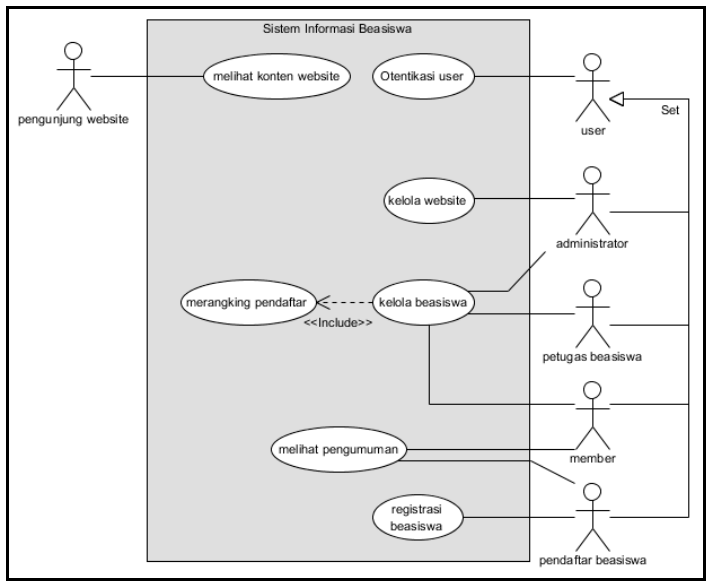

Gambar 3.3 Use Case Diagram Sistem Informasi pada Fase Inception

\subsection{Fase Elaboration}

\subsubsection{Use Case Diagram}

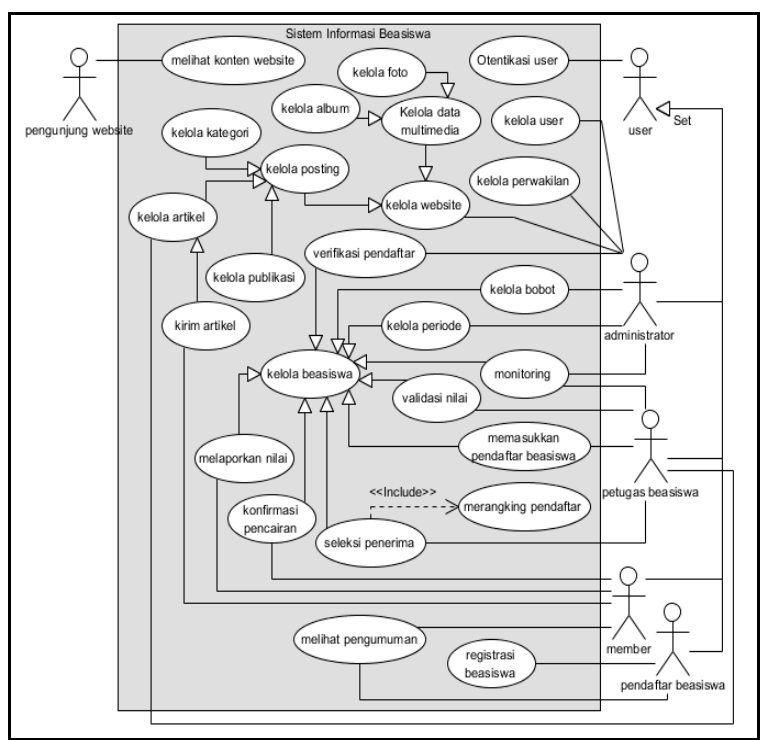

Gambar 3.4 Use Case Diagram Sistem Informasi Beasiswa Fase Elaboration

\subsubsection{Penentuan Kriteria Perangkingan}

Penerapan metode simple additive weighting membutuhkan kriteria-kriteria untuk menentukan rangking di tiap-tiap alternatif yang ada. Kriteria utama yang digunakan sebagai dasar penentuan beasiswa pada Yayasan ORBIT HAH meliputi rata-rata nilai semester atau IP, pendapatan ayah, pendapatan ibu, jumlah saudara, dan jumlah semester yang telah dijalani. 
Berdasarkan pada kriteria-kriteria yang digunakan dalam menentukan penerima beasiswa maka diperoleh kriteria-kriteria perangkingan sebagai berikut:

1) $C_{1}=$ rata-rata nilai semester atau IP di tiap semester

2) $\mathrm{C}_{2}=$ pendapatan ayah

3) $\mathrm{C}_{3}=$ pendapatan $\mathrm{ibu}$

4) $\mathrm{C}_{4}=$ jumlah saudara

5) $\mathrm{C}_{5}=$ jumlah semester yang pernah dijalani.

\subsubsection{Penentuan Nilai Rentang Kriteria Perangkingan}

Setiap alternatif atau pendaftar beasiswa memiliki nilai pada tiap kriteria yang ada. Berikut merupakan penilaian untuk setiap kriteria.

1) Kriteria rata-rata nilai semester atau IP $\left(C_{1}\right)$

Tabel 3.1 Nilai kecocokan Rata-rata nilai

\begin{tabular}{|c|l|l|c|}
\hline No & \multicolumn{1}{|c|}{$\begin{array}{c}\text { Nilai dalam } \\
\text { Rentang 10 }\end{array}$} & Rating kriteria & Nilai rating \\
\hline 1 & Nilai $<=6$ & Sangat rendah & 0 \\
\hline 2 & $6<$ Nilai $<=7$ & rendah & 2.5 \\
\hline 3 & $7<$ Nilai $<=8$ & cukup & 5.0 \\
\hline 4 & $8<$ Nilai $<=9$ & tinggi & 7.5 \\
\hline 5 & Nilai $>9$ & Sangat tinggi & 10 \\
\hline
\end{tabular}

Tabel 3.2 Nilai Kecocokan IP

\begin{tabular}{|c|l|l|c|}
\hline No & IP dalam rentang 4.00 & Rating kriteria & Nilai rating \\
\hline 1 & IP $<=2.50$ & Sangat rendah & 0 \\
\hline 2 & $2.50<\mathrm{IP}<=2.75$ & rendah & 2.5 \\
\hline 3 & $2.75<\mathrm{IP}<=3.00$ & cukup & 5.0 \\
\hline 4 & $3.00<\mathrm{IP}<=3.25$ & tinggi & 7.5 \\
\hline 5 & $\mathrm{IP}>3.25$ & Sangat tinggi & 10 \\
\hline
\end{tabular}

2) Jumlah saudara $\left(\mathrm{C}_{4}\right)$

Tabel 3.3 Nilai Keocokan Jumlah Saudara.

\begin{tabular}{|c|l|l|c|}
\hline No & \multicolumn{1}{|c|}{ Jumlah saudara } & Rating kriteria & Nilai rating \\
\hline 1 & Jumlah saudara $=1$ & Sangat rendah & 0 \\
\hline 2 & Jumlah saudara $=2$ & rendah & 2.5 \\
\hline 3 & Jumlah saudara $=3$ & cukup & 5 \\
\hline 4 & Jumlah saudara $=4$ & tinggi & 7.5 \\
\hline 5 & Jumlah saudara $>=5$ & Sangat tinggi & 10 \\
\hline
\end{tabular}

3) Jumlah semester yang pernah dijalani $\left(\mathrm{C}_{5}\right)$ Tabel 3.34 Nilai Kecocokan Jumlah Semester

\begin{tabular}{|c|l|l|c|}
\hline No & Jumlah semester & Rating kriteria & Nilai rating \\
\hline 1 & Jumlah semester $=1$ & Sangat rendah & 0 \\
\hline 2 & Jumlah semester $=2$ & rendah & 2.5 \\
\hline 3 & Jumlah semester $=3$ & cukup & 5 \\
\hline 4 & Jumlah semester $=4$ & tinggi & 7.5 \\
\hline 5 & Jumlah semester $>=5$ & Sangat tinggi & 10 \\
\hline
\end{tabular}

4) Kriteria pendapatan ayah dan ibu $\left(C_{2}\right.$ dan $\left.C_{3}\right)$ Tabel 3.2 Nilai Kecocokan Pendapatan Ayah dan Ibu

\begin{tabular}{|c|l|l|c|}
\hline No & \multicolumn{1}{|c|}{ Pendapatan } & \multicolumn{1}{|c|}{$\begin{array}{c}\text { Rating } \\
\text { kriteria }\end{array}$} & $\begin{array}{c}\text { Nilai } \\
\text { rating }\end{array}$ \\
\hline 1 & Di bawah Rp. 500.000 & rendah & 2 \\
\hline 2 & Rp. $500.000-$ Rp. 999.999 & sedang & 4 \\
\hline 3 & Rp. $1000.000-$ Rp. 1499.999 & tengah & 6 \\
\hline 4 & Rp. $1500.000-$ Rp. 1999.999 & tinggi & 8 \\
\hline 5 & Rp. 2000.000 atau lebih & sangat tinggi & 10 \\
\hline
\end{tabular}

\subsubsection{Penentuan Bobot Perangkingan Simple Additive Weighting}

Penentuan bobot perangkingan dilakukan dengan melakukan perbandingan poin kepentingan di tiap kriteria dengan jumlah keseluruhan poin. Berikut merupakan poin kepentingan dari tiap-tiap kriteria

1) $C_{1}=5$ poin
2) $C_{2}=3$ poin
3) $C_{3}=3$ poin
4) $C_{4}=2$ poin
5) $C_{5}=1$ poin

Berdasarkan poin kepentingan di tiap kriteria maka diperoleh bobot (w) sebagai berikut:

1) $\mathrm{w}_{1}=5 /(5+3+3+2+1)=5 / 14=0.36$

2) $\mathrm{w}_{2}=3 /(5+3+3+2+1)=3 / 14=0.21$

3) $\mathrm{w}_{3}=3 /(5+3+3+2+1)=3 / 14=0.21$

4) $\mathrm{w}_{4}=2 /(5+3+3+2+1)=2 / 14=0.14$

5) $\mathrm{w}_{5}=1 /(5+3+3+2+1)=1 / 14=0.07$.

\section{IMPLEMENTASI}

\subsection{Perhitungan Perangkingan}

Menggunakan Simple Additive Weighting

Perhitungan simple additive weighting dilakukan pada dua puluh pendaftar beasiswa 
orbit periode 2010-2011 perwakilan yayasan Semarang.

Tabel 4.1 Pendaftar Beasiswa Periode 2010 2011

\begin{tabular}{|c|c|c|c|c|c|}
\hline Nama & IP & $\begin{array}{c}\text { Penghasilan } \\
\text { Ayah }\end{array}$ & $\begin{array}{c}\text { Penghasilan } \\
\text { Ibu }\end{array}$ & $\begin{array}{c}\text { Jml } \\
\text { Saud } \\
\text { ara }\end{array}$ & $\begin{array}{c}\text { Jml } \\
\text { SMT }\end{array}$ \\
\hline $\begin{array}{l}\text { Yang } \\
\text { analisa }\end{array}$ & 3.10 & $\begin{array}{l}\text { Rp. } 500.000 \text { - } \\
\text { Rp. } 999.999\end{array}$ & $\begin{array}{l}\text { Di bawah Rp. } \\
500.000\end{array}$ & 4 & 6 \\
\hline $\begin{array}{l}\text { Ridwan zia } \\
\text { kusumah }\end{array}$ & 3.36 & $\begin{array}{l}\text { Rp. } 2000.000 \\
\text { atau lebih }\end{array}$ & $\begin{array}{l}\text { Di bawah Rp. } \\
500.000\end{array}$ & 6 & 6 \\
\hline $\begin{array}{l}\text { Arieyani } \\
\text { widyarti } \\
\text { indrakusum } \\
\text { a }\end{array}$ & 3.19 & $\begin{array}{l}\text { Di bawah Rp. } \\
500.000\end{array}$ & $\begin{array}{l}\text { Rp. } 500.000 \text { - } \\
\text { Rp. } 999.999\end{array}$ & 3 & 8 \\
\hline $\begin{array}{l}\text { Dewi sri } \\
\text { kurniawati }\end{array}$ & 3.59 & $\begin{array}{l}\text { Rp. } 1500.000- \\
\text { Rp. } 1999.999\end{array}$ & $\begin{array}{l}\text { Di bawah Rp. } \\
500.000\end{array}$ & 7 & 4 \\
\hline $\begin{array}{l}\text { Maula } \\
\text { mar'atus }\end{array}$ & 3.65 & $\begin{array}{l}\text { Rp. } 1500.000- \\
\text { Rp. } 1999.999\end{array}$ & $\begin{array}{l}\text { Di bawah Rp. } \\
500.000\end{array}$ & 2 & 4 \\
\hline $\begin{array}{l}\text { Okma } \\
\text { noviana }\end{array}$ & 3.29 & $\begin{array}{l}\text { Rp. } 500.000 \text { - } \\
\text { Rp. } 999.999\end{array}$ & $\begin{array}{l}\text { Di bawah Rp. } \\
500.000\end{array}$ & 5 & 6 \\
\hline $\begin{array}{l}\text { Anita hadi } \\
\text { saputri }\end{array}$ & 3.25 & $\begin{array}{l}\text { Rp. } 500.000- \\
\text { Rp. } 999.999\end{array}$ & $\begin{array}{l}\text { Di bawah Rp. } \\
500.000\end{array}$ & 5 & 6 \\
\hline $\begin{array}{l}\text { Muhammad } \\
\text { adytia } \\
\text { yanuardi }\end{array}$ & 3.90 & $\begin{array}{l}\text { Rp. } 2000.000 \\
\text { atau lebih }\end{array}$ & $\begin{array}{l}\text { Di bawah Rp. } \\
500.000\end{array}$ & 3 & 4 \\
\hline $\begin{array}{l}\text { Siti } \\
\text { sulisetyo } \\
\text { wati }\end{array}$ & 3.37 & $\begin{array}{l}\text { Rp. } 500.000- \\
\text { Rp. } 999.999\end{array}$ & $\begin{array}{l}\text { Di bawah Rp. } \\
500.000\end{array}$ & 2 & 6 \\
\hline Mustinah & 3.61 & $\begin{array}{l}\text { Di bawah Rp. } \\
500.000\end{array}$ & $\begin{array}{l}\text { Di bawah Rp. } \\
500.000\end{array}$ & 4 & 6 \\
\hline $\begin{array}{l}\text { Eny } \\
\text { rohmawati }\end{array}$ & 3.77 & $\begin{array}{l}\text { Rp. } 1000.000- \\
\text { Rp. } 1499.999\end{array}$ & $\begin{array}{l}\text { Di bawah Rp. } \\
500.000\end{array}$ & 3 & 6 \\
\hline $\begin{array}{l}\text { Ahmad } \\
\text { zaini }\end{array}$ & 3.42 & $\begin{array}{l}\text { Di bawah Rp. } \\
500.000\end{array}$ & $\begin{array}{l}\text { Rp. } 500.000- \\
\text { Rp. } 999.999\end{array}$ & 2 & 4 \\
\hline Sudarto & 3.23 & $\begin{array}{l}\text { Di bawah Rp. } \\
500.000\end{array}$ & $\begin{array}{l}\text { Di bawah Rp. } \\
500.000\end{array}$ & 4 & 6 \\
\hline $\begin{array}{l}\text { Agung } \\
\text { wibawa }\end{array}$ & 3.24 & $\begin{array}{l}\text { Rp. } 500.000- \\
\text { Rp. } 999.999\end{array}$ & $\begin{array}{l}\text { Rp. } 500.000- \\
\text { Rp. } 999.999\end{array}$ & 3 & 4 \\
\hline Nor hayati & 3.29 & $\begin{array}{l}\text { Di bawah Rp. } \\
500.000\end{array}$ & $\begin{array}{l}\text { Di bawah Rp. } \\
500.000\end{array}$ & 7 & 4 \\
\hline Tuti aliyah & 3.69 & $\begin{array}{l}\text { Rp. } 500.000- \\
\text { Rp. } 999.999\end{array}$ & $\begin{array}{l}\text { Rp. } 500.000- \\
\text { Rp. } 999.999\end{array}$ & 9 & 8 \\
\hline $\begin{array}{l}\text { Dwi laela } \\
\text { sari }\end{array}$ & 3.63 & $\begin{array}{l}\text { Di bawah Rp. } \\
500.000\end{array}$ & $\begin{array}{l}\text { Di bawah Rp. } \\
500.000\end{array}$ & 3 & 6 \\
\hline Ali ma'ruf & 3.70 & $\begin{array}{l}\text { Rp. } 1000.000- \\
\text { Rp. } 1499.999\end{array}$ & $\begin{array}{l}\text { Rp. } 1500.000 \\
\text { - Rp. } \\
1999.999\end{array}$ & 4 & 4 \\
\hline $\begin{array}{l}\text { Hendrik } \\
\text { khomaruddi } \\
\text { n }\end{array}$ & 3.04 & $\begin{array}{l}\text { Rp. } 500.000- \\
\text { Rp. } 999.999\end{array}$ & $\begin{array}{l}\text { Di bawah Rp. } \\
500.000\end{array}$ & 1 & 6 \\
\hline Nuryanti & 3.12 & $\begin{array}{l}\text { Rp. } 500.000- \\
\text { Rp. } 999.999\end{array}$ & $\begin{array}{l}\text { Di bawah Rp. } \\
500.000\end{array}$ & 2 & 6 \\
\hline
\end{tabular}

Berdasarkan nilai rentang kecocokan kriteria maka diperoleh matriks keputusan X.

$\mathbf{X}=\mid \begin{array}{ccccc}7.5 & 4 & 2 & 7.5 & 10 \\ 10 & 10 & 2 & 10 & 10 \\ 7.5 & 2 & 4 & 5 & 10 \\ 10 & 8 & 2 & 10 & 7.5 \\ 10 & 8 & 2 & 2.5 & 7.5 \\ 10 & 4 & 2 & 10 & 10 \\ 7.5 & 4 & 2 & 10 & 10 \\ 10 & 10 & 2 & 5 & 7.5 \\ 10 & 4 & 2 & 2.5 & 10 \\ 10 & 2 & 2 & 7.5 & 10 \\ 10 & 6 & 2 & 5 & 10 \\ 10 & 2 & 4 & 2.5 & 7.5 \\ 7.5 & 2 & 2 & 7.5 & 10 \\ 7.5 & 4 & 4 & 5 & 7.5 \\ 10 & 2 & 2 & 10 & 7.5 \\ 10 & 4 & 4 & 10 & 10 \\ 10 & 2 & 2 & 5 & 10 \\ 10 & 6 & 8 & 7.5 & 7.5 \\ 7.5 & 4 & 2 & 0 & 10 \\ 7.5 & 4 & 2 & 2.5 & 10\end{array}$

Pengambilan keputusan memberikan vektor bobot sebagai berikut :

$$
\mathrm{w}=\left|\begin{array}{lllll}
0.36 & 0.21 & 0.21 & 0.14 & 0.07
\end{array}\right|
$$

Berdasarkan matrik keputusan X maka proses perangkingan selanjutnya adalah normalisasi matrik $\mathrm{X}$, hasil normalisasi matriks $\mathrm{X}$ sebagai berikut:

$$
\mathrm{X}_{\text {normal }}=\left|\begin{array}{lllll}
0.750 & 0.500 & 1.000 & 0.750 & 1.000 \\
1.000 & 0.200 & 1.000 & 1.000 & 1000 \\
0.750 & 1.000 & 0.500 & 0.500 & 1.000 \\
1.000 & 0.250 & 1.000 & 1.000 & 0.750 \\
1.000 & 0.250 & 1.000 & 0.250 & 0.750 \\
1.000 & 0.500 & 1.000 & 1.000 & 1.000 \\
0.750 & 0.500 & 1.000 & 1.000 & 1.000
\end{array}\right|
$$




$$
\left|\begin{array}{lllll}
1.000 & 0.200 & 1.000 & 0.500 & 0.750 \\
1.000 & 0.500 & 1.000 & 0.250 & 1.000 \\
1.000 & 1.000 & 1.000 & 0.750 & 1.000 \\
1.000 & 0.333 & 1.000 & 0.500 & 1.000 \\
1.000 & 1.000 & 0.500 & 0.250 & 0.750 \\
0.750 & 1.000 & 1.000 & 0.750 & 1.000 \\
0.750 & 0.500 & 0.500 & 0.500 & 0.750 \\
1.000 & 1.000 & 1.000 & 1.000 & 0.750 \\
1.000 & 0.500 & 0.500 & 1.000 & 1.000 \\
1.000 & 1.000 & 1.000 & 0.500 & 1.000 \\
1.000 & 0.333 & 0.250 & 0.750 & 0.750 \\
0.750 & 0.500 & 1.000 & 0.000 & 1.000 \\
0.750 & 0.500 & 1.000 & 0.250 & 1.000
\end{array}\right|
$$

Setelah diperoleh matrik keputusan yang ternormalisasi, tahap selanjutnya melakukan perkalian matrik $\mathrm{w} *$ Xnormal dan nilai dari penjumlahan hasil perkalian digunakan untuk menentukan rangking alternatif.

1) Yang Analisa

$=(0.750 \times 0.36)+(0.500 \times 0.21)+(1.000$ $\mathrm{x} 0.21)+(0.750 \mathrm{x} 0.14)+(1.000 \mathrm{x} 0.07)$ $=0.760$

2) Ridwan Zia Kusumah

$=(1.000 \mathrm{x} 0.36)+(0.200 \mathrm{x} 0.21)+(1.000$ $\mathrm{x} 0.21)+(1.000 \times 0.14)+(1.000 \times 0.07)$ $=0.822$

3) Arieyani Widyarti Indrakusuma $=(0.750 \times 0.36)+(1.000 \times 0.21)+(0.500 \times$ $0.21)+(0.500 \times 0.14)+(1.000 \times 0.07)$ $=0.725$

4) Dewi Sri Kurniawati

$=(1.000 \times 0.36)+(0.250 \times 0.21)+(1.000 \times$ $0.21)+(1.000 \times 0.14)+(0.750 \times 0.07)$ $=0.815$

5) Maula Mar'atus $=(1.000 \times 0.36)+(0.250 \times 0.21)+(1.000 \times$ $0.21)+(0.250 \times 0.14)+(0.750 \times 0.07)$ $=0.710$

6) Okma Noviana

$=(1.000 \times 0.36)+(0.500 \times 0.21)+(1.000 \times$ $0.21)+(1.000 \times 0.14)+(1.000 \times 0.07)$

$=0.885$

7) Anita Hadi Saputri
$=(0.750 \times 0.36)+(0.500 \times 0.21)+(1.000 \mathrm{x}$ $0.21)+(1.000 \times 0.14)+(1.000 \times 0.07)$ $=0.795$

8) Muhammad Adytia Yanuardi $=(1.000 \times 0.36)+(0.200 \times 0.21)+(1.000 \times$ $0.21)+(0.500 \times 0.14)+(0.750 \times 0.07)$ $=0.735$

9) Siti Sulisetyo Wati $=(1.000 \times 0.36)+(0.500 \times 0.21)+(1.000 \times$ $0.21)+(0.250 \times 0.14)+(1.000 \times 0.07)$ $=0.780$

10) Mustinah $=(1.000 \times 0.36)+(1.000 \times 0.21)+(1.000 \times$ $0.21)+(0.750 \times 0.14)+(1.000 \times 0.07)$ $=0.955$

11) Eny Rohmawati $=(1.000 \times 0.36)+(0.333 \times 0.21)+(1.000 \times$ $0.21)+(0.500 \times 0.14)+(1.000 \times 0.07)$ $=0.780$

12) Ahmad Zaini $=(1.000 \times 0.36)+(1.000 \times 0.21)+(0.500 \times$ $0.21)+(0.250 \times 0.14)+(0.750 \times 0.07)$ $=0.763$

13) Sudarto $=(0.750 \times 0.36)+(1.000 \times 0.21)+(1.000 \times$ $0.21)+(0.750 \times 0.14)+(1.000 \times 0.07)$ $=0.865$

14) Agung Wibawa $=(0.750 \times 0.36)+(0.500 \times 0.21)+(0.500 \times$ $0.21)+(0.500 \times 0.14)+(0.750 \times 0.07)$ $=0.603$

15) Nor Hayati $=(1.000 \times 0.36)+(1.000 \times 0.21)+(1.000 \times$ $0.21)+(1.000 \times 0.14)+(0.750 \times 0.07)$ $=0.973$

16) Tuti Aliyah $=(1.000 \times 0.36)+(0.500 \times 0.21)+(0.500 \times$ $0.21)+(1.000 \times 0.14)+(1.000 \times 0.07)$ $=0.780$

17) Dwi Laela Sari $=(1.000 \times 0.36)+(1.000 \times 0.21)+(1.000 \times$ $0.21)+(0.500 \times 0.14)+(1.000 \times 0.07)$ $=0.920$

18) Ali Ma'ruf $=(1.000 \times 0.36)+(0.333 \times 0.21)+(0.250 \times$ $0.21)+(0.750 \times 0.14)+(0.750 \times 0.07)$ $=0.640$

19) Hendrik Khomaruddin $=(0.750 \times 0.36)+(0.500 \times 0.21)+(1.000 \times$ $0.21)+(0.000 \times 0.14)+(1.000 \times 0.07)$ 
$=0.655$

20) Nuryanti

$$
\begin{aligned}
& =(0.750 \times 0.36)+(0.500 \times 0.21)+(1.000 \times \\
& 0.21)+(0.250 \times 0.14)+(1.000 \times 0.07) \\
& =0.690
\end{aligned}
$$

Berdasarkan hasil perhitungan dari penjumlahan hasil perkalian $\mathrm{w} *$ Xnormal maka Nor Hayati merupakan alternatif terbaik sebagai penerima beasiswa. Alternatif yang memliki nilai tertinggi merupakan alternatif terbaik untuk menerima beasiswa.

\subsection{Penerapan Simple Additive Weighting} pada Sistem Informasi
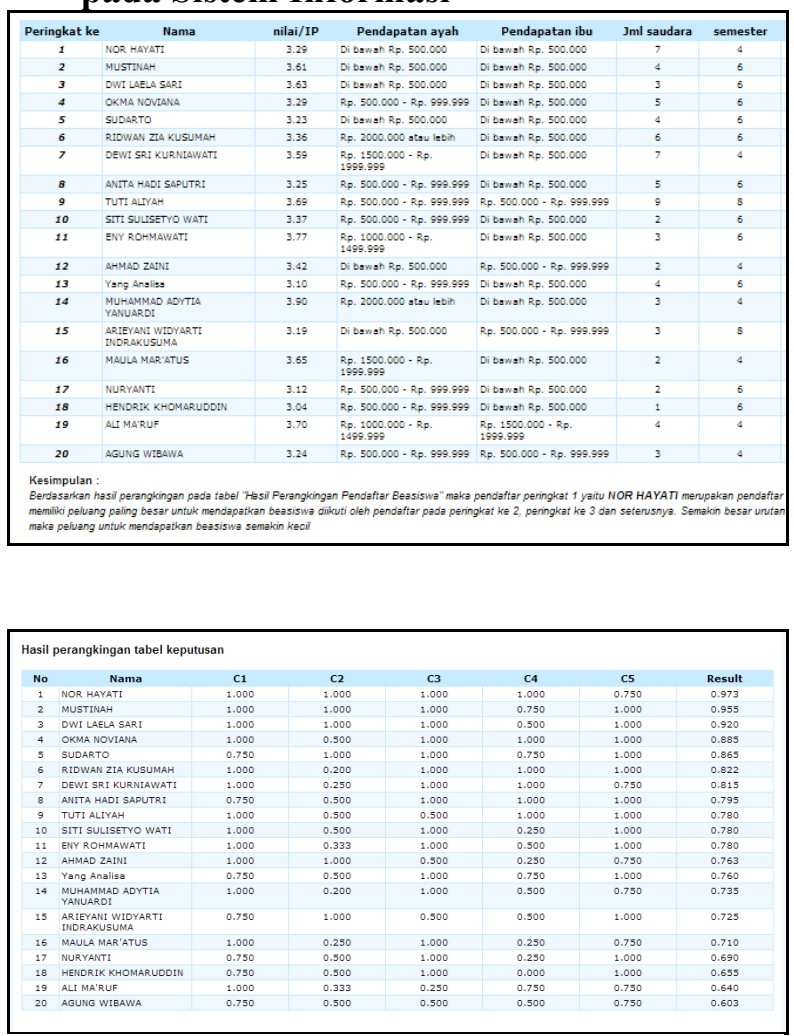

\section{KESIMPULAN DAN SARAN}

\subsection{Kesimpulan}

Penyusunan jurnal ini menghasilkan kesimpulan sebagai berikut:

1) Dihasilkan Sistem Informasi Beasiswa Yayasan Amal Abadi Beasiswa Orang Tua Bimbing Terpadu Hasri Ainun Habibie yang dapat digunakan untuk melakukan pendaftaran beasiswa secara online.

2) Pengembangan sistem informasi menggunakan metode pengembangan perangkat lunak unified process (UP) menjadikan proses pengembangan perangkat lunak lebih mudah untuk ditelusuri dengan karakteristik use case driven.

3) Penerapan metode simple additive weighting menghasilkan perangkingan yang dapat digunakan sebagai pertimbangan pengambil keputusan.

\subsection{Saran}

Saran-saran sebagai bahan pertimbangan untuk pengembangan sistem informasi lebih lanjut adalah sebagai berikut:

1) Penambahan forum pada sistem informasi sebagai sarana komunikasi antar penerima beasiswa dan pengurus yayasan sehingga muncul ide-ide dalam pengembangan diri penerima beasiswa.

2) Penambahan fasilitas import dan eksport file pada data beasiswa sehingga memudahkan dalam pengolahan data yang lebih lanjut seperti pengolahan menggunakan aplikasi office.

3) Penambahan fasilitas kirim file dan validasi hasil scan data pendaftaran dan lampiranlampiran penunjang sehingga mempercepat proses pendaftaran beasiswa dan menghilangkan ketergantungan terhadap pihak ketiga seperti jasa pengiriman.

\section{DAFTAR PUSTAKA}

[1] _.2001.Anggaran Dasar Yayasan Amal Abadi Beasiswa ORBIT, Jakarta.

[2] Ambler, Scott W. 2004.The Object Primer, Third Edition.Cambridge :Cambridge University Press

[3] Daqiqil, Ibnu, Id.2011.Framework CodeIgniter, Sebuah Panduan dan Best Practice.Pekanbaru.

[4] Hunt, John. 2003. Guide to the Unified Process featuring UML, Java and Design Patterns. London : Springer.

[5] Jacobson, Ivar, dkk. 1999. The Unified Software Development Process. Addison Wesley : Boston.

[6] Jogiyanto.2003. Sistem Teknologi Informasi. Yogyakarta: Penerbit Andi. 
[7] Pressman RS. 2001. Software Engineering : A Practitioner's Approach. New York: McGraw - Hill.

[8] Rao, R. Venkata.2007. Decision Making in the Manufacturing Environment. London : Springger.

[9] Rumbaugh.James.et all. 1999.The Unified Modelling Language Reference Manual. Boston : Addison Wesley
[10] Turban, Efraim, dkk. 2005. Decision Support System and Intelligent Systems. Yogyakarta : Penerbit Andi.

[11] Welling, Luke, et all. 2009.PHP and MySQL Web Development, Fourth Edition.

Boston : Addison Wesley 